\title{
FEATURES OF THE DEVELOPMENT OF THE NEO-MOORISH STYLE ON THE EXAMPLE OF RUSSIA AND FRANCE
}

Summary: A comparative analysis of the formation and development of the Neo-Moorish style in the architecture and interiors of France and Russia in the $19^{\text {th }}$ century is presented in the article. How did the interest in studying the architecture of medieval Moors form in these countries? What are the main differences and similarities in the development of the Neo-Moorish style in Russia and France?

In the $19^{\text {th }}$ century, the first manifestations of the oriental theme appeared to a large extent owing to the work of writers and artists. The mysterious world of the East became a rich source of new plots, palette, exotic customs, and architectural forms. In parallel with literature and painting, the oriental theme was developing in architecture and interior design, and it would later flourish in copying the Moorish style. Among the monuments of medieval Moors, the Alhambra Palace, built in the Emirate of Granada in the period from the $13^{\text {th }}$ to the $15^{\text {th }}$ centuries, became an architectural model for European architects. The French world exhibitions, on which architectural and historical pavilions were exhibited, were a significant source of the proliferation of the Neo-Moorish style in Europe. Russian architects such as Paul Notbek and Carl Rachau also made a significant contribution to the study of the Alhambra. Recognized both in Russia and in Europe, the results of their work allowed St. Petersburg ar-

In Europe, an increased interest in the art of the East had been developing throughout the $18^{\text {th }}$ century. In architecture, the first manifestations of Orientalism are mainly found in the Europeanized Chinese style of Chinoiserie as one of the Rococo sub-styles. At the beginning of the $19^{\text {th }}$ century, interest in Mus- chitects to have original samples of Moorish architecture and to develop this style in many St. Petersburg interiors with a high degree of skill of their work during the peak of historicism development.

In the second half of the $19^{\text {th }}$ century, the Moorish style spread throughout Europe and became an international historical oriental style. In each country, borrowings showed their own characteristics and developmental features due to cultural, political, and geographical influence. In France, the Moorish style was actively borrowed not only for interior decoration but also in the construction of public and commercial buildings such as casinos, cafes, thermal stations. In Russia, the Moorish style was used mainly in palaces and mansions of the highest nobility and the bourgeoisie. In France, the Mauresque style took on various forms and had different sources, whereas in Russia it referred mainly to the historical examples of the Alhambra. Thus, France and Russia participated in the pan-European trend of the Neo-Moorish style; however, each country has developed its own variation of this oriental style of the period of historicism.

Keywords: Neo-Moorish style, oriental movement, interior design, oriental style historical borrowings, Orientalism, Alhambra, historicism, comparative history of the art of France and Russia.

lim cultures increased under the influence of Romanticism. And already by the middle of the $19^{\text {th }}$ century, the Neo-Moorish style became the most demanded historical oriental borrowing in the architecture and interior decoration of France and Russia. In France, the borrowing of the Moorish style developed not 
only as the result of the pan-European trend of historicism but due to the colonization of North Afri$\mathrm{Ca}$, the territory of which, along with Andalusia, is considered to be the historical region of this movement. Russian Orientalism had two sources: it was connected with the expansion of the Russian Empire to the East (the Caucasus and Central Asia) and at the same time influenced by Western Orientalism, which explains the popularity of the Neo-Moorish style among the Russian nobility.

Both in France and in Russia, the first ideas about the East developed owing to painting and literature. In 1829, French writer Victor Hugo (1802-1885) noted in the preface to his Les Orientales collection: "Today, we more than ever deal with the East. ... In the age of Louis XIV, we were Hellenists, now we are Orientalists" [23, p. 6]. Along with the existing eastern cultures, with which artists and writers became acquainted during scientific expeditions and colonial expansion, interest in the eastern cultures of the past, which left behind a rich architectural and decorative heritage, was developing. According to the romanticists of the $19^{\text {th }}$ century, these monuments included the medieval heritage of the Eastern Moors. Moorish art embraces the artistic culture of North Africa and Southern Spain from the time of Arab rule. The main architectural example of this style is the Alhambra Palace, built in the Emirate of Granada from the $13^{\text {th }}$ to the $15^{\text {th }}$ centuries.

In 1846, while traveling in Spain with artists Louis Boulanger (1806-1867) and P. F. Eugène Giraud (1806-1881), Alexander Dumas (1802-1870) spent several days in Granada, which he described in the book From Paris to Cadiz (1847-1848). Dumas, like many other writers, conveyed his admiration for the architecture, the decoration of the halls and courtyards of the Alhambra: "When you find yourself in a large courtyard, which bears three different names, Myrtle Courtyard, Courtyard with a Canal or Courtyard with a Pool, (...) you will become five centuries younger, and you will definitely prefer the East to the West" [16, p. 281]. Subsequently, the Eastern theme developed in Dumas's literary works (in particular, in the novel Count of Monte Cristo), thereby participating in the keenness of many French romantic writers on Orientalism. Drawings and paintings by the artist Adrian Dauzats (1804-1868) from his journeys are another interesting evidence in which he reflected his participation in an expedition to the Middle East and the study of Moorish heritage in Granada, Seville, Cordoba in 1836. (ill. 1)
Thanks to the culture of the East, artists showed the viewers new scenic views of Islamic architecture, a vibrant color palette, plot compositions of oriental life, and history. The Eastern genre in France was represented by Algerian Women in a Harem (1849) by E. Delacroix (1798-1863), T. Chasserio's (1819-1856) Moorish Dance with Scarves (1849), Palace of Punishment at the Alhambra in Granada (1878) by artist E. M. F. de Boilecont (1849-1923) and many others.

For Russian writers and artists of the $19^{\text {th }}$ century, the Crimea and the Caucasus after becoming part of the Russian Empire at the expense of Turkey and Persia initially became a source of inspiration for oriental themes. For example, Alexander Pushkin (17991837), under the influence of Romanticism and his own observations, developed an oriental theme in a number of works (The Fountain of Bakhchisarai) and in his notes Travel to Arzrum, in which he described the luxurious Tiflis baths and talked about his visit to the current Turkish harem, concluding: "In this way, I saw a harem: not every European has succeeded in this. Here is the basis for an oriental novel" [10, p. 408]. Later, Orientalism expanded its borders following a pan-European trend, and some artists and writers turned directly to the Moorish theme. For example, V.P. Botkin (1811-1869), traveling the Iberian Peninsula in 1845, in his Letters on Spain (1857), described the exoticism of this country due to the cultural influence and exceptional architectural heritage of the Arab Moors, partially preserved in Seville, Cordoba, and the Alhambra. Botkin wrote: "The Moorish element not only left deep traces in Andalusia: it merged here with everything, you feel it in the folk tunes of fandango, and in the language, and in customs, and in habits" [3, p. 75]. The author notes that for the people of $19^{\text {th }}$-century Europe, the character and customs of the East remain mysterious and alien to European culture.

At the beginning of the $19^{\text {th }}$ century, following the example of artists and writers, European architects discovered the beauty and richness of Moorish architecture. Many people started to visit Spanish Andalusia not only to get acquainted with its architecture but also to study in detail, measure, make models and casts. The studied material was published in separate albums, as study guides; lecture courses on Moorish decor were developed.

In 1836, a French artist and photographer specializing in architecture, J.P. Girault de Prangey (1802-1892), published a comparative analysis of Andalusian, Arab and Egyptian architectural monu- 


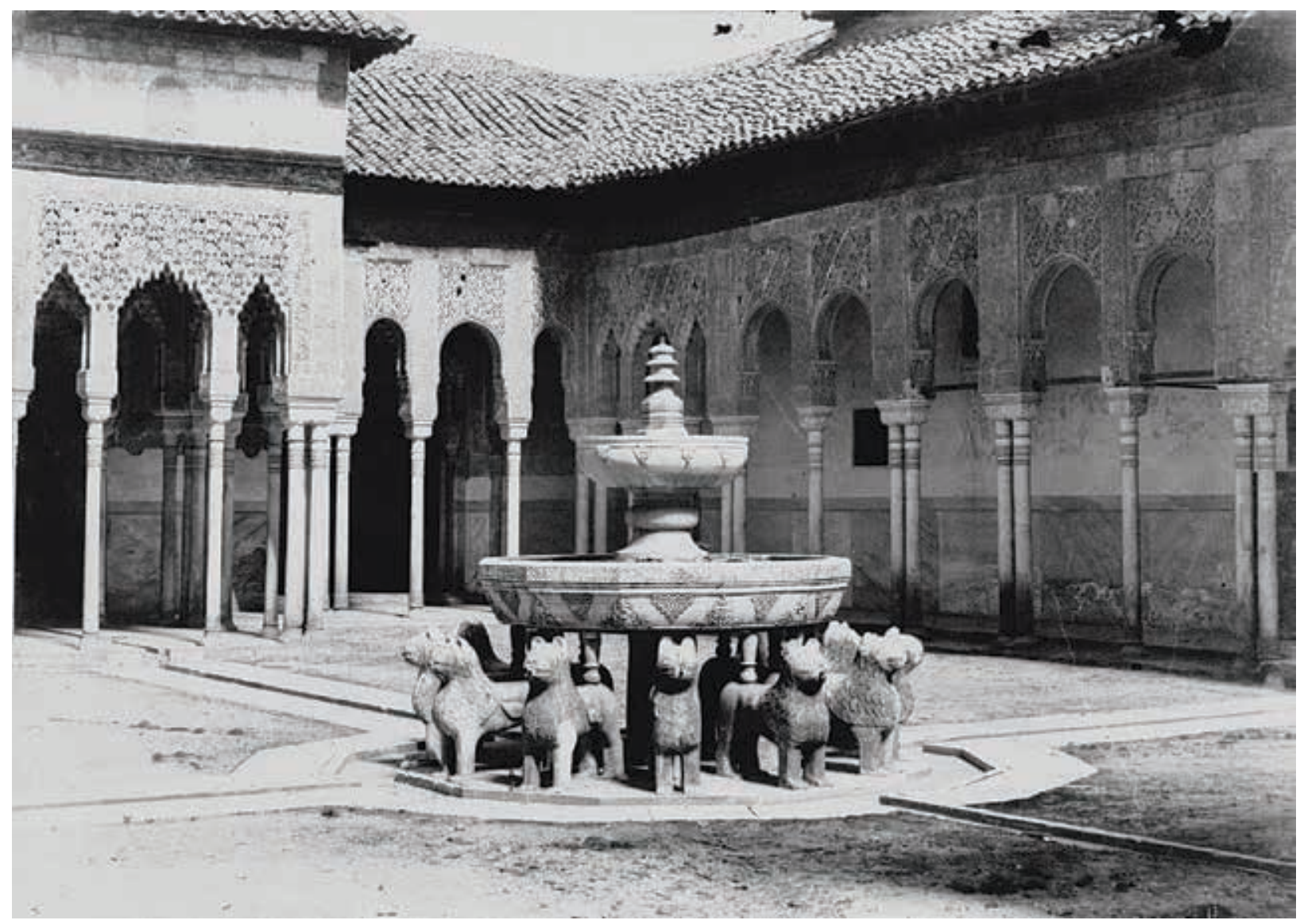

IIl. 2. Gustave de Beaucorps (Gustave de Beaucorps). Lion's yard. Alhambra Grenada. 1858. Photograph positive - albumin papercalotype 26.6×38.3. National Library of France. Paris

ments in the book ${ }^{1}$ Arab and Moorish Constructions in Cordoba, Seville, and Granada with Sketches and Measurements in 1832 and 1833, 1836-1839 [20]. In this publication, the author considers the Alhambra as the most perfect example of Moorish architecture. On his trip to the East, J. F. Girault de Prangey was one of the first to use the possibilities of daguerreotypes, thanks to which unique images of monuments of oriental architecture and their ornaments have been preserved to this day. With the development of calotype ${ }^{2}$, the first photographs of the Alhambra halls, taken by Jean Laurent (1816-1886) and Gustave de Beaucorps (1825-1906) [14] (ill. 2), appeared in France in the late 1850s.

In Russia, by the middle of the $19^{\text {th }}$ century, students of the Imperial Academy of Arts began to become interested in the Russian East, visiting Central Asia and the Caucasus [9, p. 217]. In addition to studying classical monuments, the Moorish architecture of Andalusia was added to the Academy's

1. One of the original copies in French is stored in the Russian National Library of St. Petersburg.

2. Calotipia from the Greek $\kappa \alpha \lambda$ ó " "beautiful" and túmo "imprint" is an early photographic process based on the use of paper saturated with iodine silver. pensioner routes in Europe. Among the pensioner works, there were works devoted to the Moorish architecture of the Alhambra, recognized for their mastery and which received awards not only in Russia but also abroad.

The work of Paul Notbek (1824-1877), who had worked in the Alhambra on sketches of Moorish architecture for ten years, creating models of separate halls and casts of ornaments, is of particular interest. Owing to Notbek's works, which were delivered to Russia, a department devoted to Moorish architecture and decor opened in the museum of the Imperial Academy of Arts. The exposition consisted of 284 items, which included the Hall of Two Sisters in the amount of $1 / 4$ of the real size, the Halls of the Abenserkhs in $1 / 12$ of the size, a model of one wall from the Hall of the Messengers in $1 / 8$ of the size, one half of the Lion's Court in $1 / 12$ of the size and others [2, p. 40-42]. The collection also included authentic Moorish capitals, which Notbek was able to acquire. Currently, part of the preserved collection of Notbek's models and casts of the Alhambra is in the Research Museum of the Russian Academy of Arts in St. Petersburg. 
Paul Notbek was awarded an honorary fellowship at the Imperial Academy of Arts and awarded the Order of St. Anne of the $3^{\text {rd }}$ degree [26, p. 21] for the creation of Moorish models and casts.

Notbek's work in the Alhambra was continued by other scholars of the Imperial Academy of Arts, among whom Carl Rachau (1830-1880) and Carl Colman (1835-1889) distinguished themselves. Praised in France, the restoration of the Infant Tower in the Alhambra Palace in Granada was one of the results of their joint work during their stay in Andalusia. The following information is given about this event in the Zodchiy journal: "It is known, however, that his excellent work - the project of restoring the Alhambra Palace in Grenada made in collaboration with his fellow pensioner C. Colman, was a surprise and was approved in Europe even before his arrival in St. Petersburg: it was awarded the gold medal at the Paris exhibition of 1862, and in Munich, it was awarded an approving honorary diploma. Having returned to St. Petersburg in 1864, C. Rachau was elevated to the rank of academician" [6, p.12-13]. According to French sources, Russian architects presented the restoration project in 1863 [22] at the annual Paris Salon, organized by the French Ministry of the Imperial House and Fine Arts [18, p. 387].

A detailed study of the medieval Moorish monuments of Spain, especially the Alhambra, contributed to the rapid development of the borrowing of the Neo-Moorish style in architecture and interior design. This oriental style became part of historicism, which had replaced the classical style. In the second half of the $19^{\text {th }}$ century, in the absence of one "big style" for this period, all movements were recognized as equivalent. Such an approach was later called eclecticism, which means "reasonable choice" in Greek. Interior design in imitative styles was done in stucco finish, and new low-cost methods of manufacturing decorative forms were developed. Various stylistic borrowings were combined in one architectural space. Rococo, Gothic, French classics, etc. were becoming especially popular among them. The Moorish interior, as one of the artistic styles of the past, also became part of the "smart choice" of architects.

Recreating the historical style of Moorish architecture, architects borrowed its most characteristic elements: thin columns, arches (pointed, horseshoe, three-lobed), stalactites in arches and niches. Windows and doors, closed with carved gilded gratings made of thin alabaster, wood or forged metal, were essential elements of the decor. Arabesque acted as the main ornament, extending almost over the entire surface of the walls. Kufic inscriptions complemented the decorative finish [12, p. 103]. The polychromy and facture of the interior was very diverse.

Architects designed Eastern interiors not only under the influence of the development of historicism but also at the request of the customers themselves, who visited the eastern countries. Writers, travelers, and representatives of the bourgeoisie were among them. To this day, the Moorish salon of French writer Alexander Dumas (1802-1870) remains one of the most striking examples. In the Monte Cristo palace in the Neo-Renaissance style built near Paris (1847), he commissioned Tunisian masters to design the Moorish salon (French: Salon Mauresque) in the likeness of those samples that the writer saw in Spain and in North Africa. The walls and ceiling of the cabin were covered with carved stucco ornament. Whimsical stucco carvings alternated with stucco bas-relief stalactites on the walls. Three massive horseshoe-shaped arches divided the interior into two parts. Lamps with colored glass, oriental furniture, incense burners, carved tables complemented the interior. Multi-colored stainedglass windows accentuated the eclectic nature of the mid-19th century interior (ill. 3).

In France, not only interiors of palaces and private mansions were designed in the Moorish style as was in Russia. This trend clearly manifested itself in the construction of public buildings. To a large extent, this was facilitated by the rapid development of the economy and the expansion of building types according to their function: new hotels, banks, apartment buildings, covered markets, train stations, recreation areas were designed.

The exoticism of the East attracted the French bourgeoisie for a change of scenery and a pleasant pastime. In the spa town of Vichy, a cafe in the Mauresque style (from French: Moorish), designed by French architect Antoine Percilly (1858-1928), was built in 1898. In the 1860s, the Southern Railways company, led by the Pereire brothers, erected a luxury ensemble of winter villas, some of which were stylized in Moorish style [19, p. 202], in the town of Arcachon. Three years later, a casino by engineer Paul Régnauld (1827-1879) was built for wealthy clients of Arcachon in 1863. The building was completed in the Spanish-Moorish style for which the structural and decorative elements of the Alhambra Palace in Grana$\mathrm{da}$ and the mosque in Cordoba were borrowed [25]. 


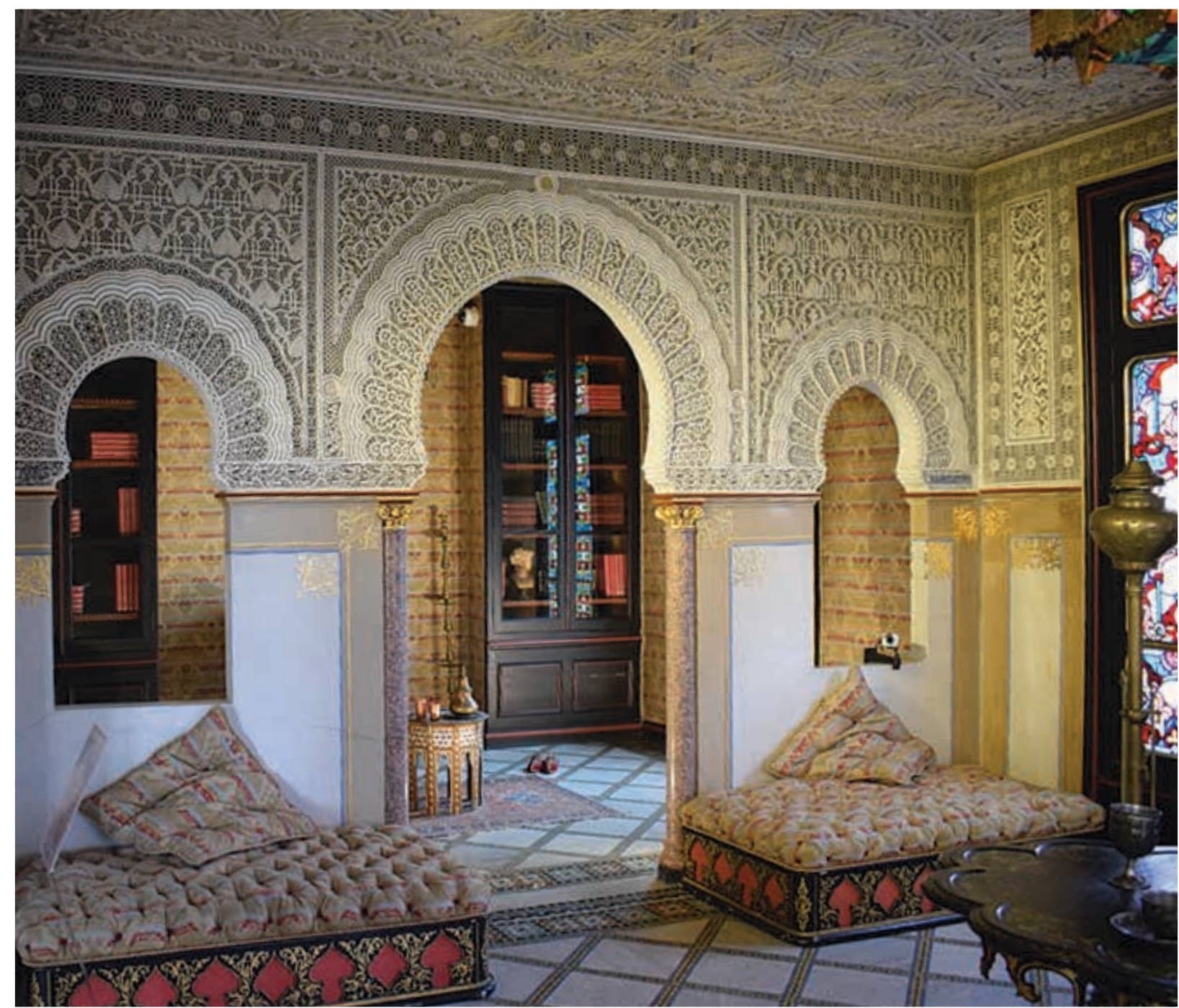

IIl. 3. Moorish Salon in Monte Cristo Castle. Evelyn. France. 1846. Masters: Hadj Younis, Mohammed Younis. Photo by the author, 2019

In France, the construction of entire ensembles in the Neo-Moorish style can be explained by the influence of the pan-European trend as well as French colonial politics in North Africa. It is noteworthy that French architects designed structures in the Mauresque style not only in France but also in its Muslim colonies (Algeria, Tunisia). In their works, architects actively borrowed local patterns and variations of the Moorish style, often supplementing them with individual elements of European architecture.

World exhibitions in European capitals were another source of widespread fashion in oriental architecture and arts and crafts. The most liked models were purchased from their creators or copies of them were ordered. In Paris, architect Carle von Diebitsch (1819-1869) presented the Moorish Pavilion in the Prussian section at the 1867 exhibition. The interior decoration of the pavilion was fully completed according to Spanish-Moorish patterns, including furniture and fabrics. A large chandelier in the Moorish style with multi-colored glass, under which a fountain was located as an integral part of the Moorish design [17], was the center of the composition of the pavilion.

On the occasion of the 1878 World Exhibition, the Trocadero Palace, designed by the architects of the Napoleon III period, Gabriel Davioud (1824-1881) and Jules Bourdais (1835-1915), was built in Paris. The building was designed with elements of Moorish and Byzantine architecture at the same time. The Moorish tower of the Giralda in Seville was the prototype for the forms of the Moorish borrowings [25].

Simultaneously, a hall in the Alhambra style was designed according to the project of French architect Henri Blondel (1821-1897) [15] for this exhibition at the Continental Hotel, which was one of the symbols of Parisian luxury. The Moorish room at the Continental Hotel was distinguished by rich wall decoration with a stylized floral and geometric ornament. The openwork horseshoe-shaped and multi-lobed 
arches supported by thin double columns with patterned capitals were borrowed from the architectural elements decorating the hall. A richly ornamented cornice complemented the decoration. Due to large arched windows there was good interior lighting during daylight. The interior decoration was supplemented with stylized lamps, patterned drapery fabrics, low sofas, and an abundance of flowers (ill. 4).

Neo-Moorish motifs were used not only in architectural forms and interior design but also in decorative and applied art. For example, in France, the ornament of the Andalusian decor has been reproduced on the wallpaper of Desfossé et Karth manufacturers since 1857 [19 p. 188].

In Russia, the Turkish style was the leading Eastern borrowing in the first half of the $19^{\text {th }}$ century due to cultural interaction with the Ottoman Empire, owing to which Russia expanded its borders from the end of the $19^{\text {th }}$ century. Objects of Turkish everyday life, a collection of weapons appear in the interiors of the Russian nobility; oriental clothing, fabrics, hats come into fashion. Oriental rooms and often pavilions in adjacent gardens were designed to store such collections in the grand-ducal palaces and mansions.

Under the influence of Western Europe, the NeoMoorish style, which was widely used in Russia, was gradually added to Turkish borrowing. Modern Western European researchers note the importance of St. Petersburg in a comparative study of the development of this style: "St. Petersburg is a city where interiors in the Neo-Moorish style are widely presented, and where many of them have survived to this day, unlike in Western Europe" [21].

In 1839-1840 A. Bryullov (1798-1877) designed the Moorish bathroom for the Empress at the Winter Palace. It became the first example of neo-Moorish borrowing in Russia [24]. In the book The Renewal of the Winter Palace in St. Petersburg, Russian writer A. Bashutsky (1803-1876) left a description of the first interior in Moorish style, which confirms the enthusiastic perception of contemporaries of this historical borrowing: "all the luxury of the Grenadian Moors; the wondrous nature of the magical inventions of the wayward art of the East is imprinted here with complete trueness. (...). Yes, the artist stole all this from the Aljambra (the spelling of the author), and surely no one would blame him for this abduction. Relief, in different colors, gold ornaments, and arabesques as if lie on the walls and the arch, covering the room with fantastic patterns from top to bottom; in some places, a column of a wonderful style rises; (...) a marble deepened bathtub, under a mirror, hot or cold water flows like a crystal spring, first into a huge sink, and from it, cascades into the bath" [1, p. 117]. Judging by Bashutsky's description, architect $A$. Bryulov laid the foundation for the development of the Neo-Moorish style in Russia already at the end of the 1830s.

In the Vladimir Palace (Palace Embankment, 26) of Prince Vladimir Alexandrovich, rebuilt in 1867-1872, architect A. Rezanov (1817-1887) designed a small boudoir in the Neo-Moorish style in the apartments of the princess.

The decoration of the boudoir, described in the Architect journal from 1875 [4, p. 89-90], is well preserved to this day. In plan, it is a small chamber room the only window of which opens onto the Neva and the Peter and Paul Fortress. The contrast of finishing materials emphasizes the three-part division of the walls. The lower belt is painted to imitate the tiles of the halls of the Alhambra, and the middle is covered with stucco gypsum ornaments. The architect brought the main wealth of ornamentation to the ceiling, to its arches, and to architectural elements. (ill. 5).

In addition to boudoirs and bathrooms, the Moorish style was widely used in the design of cabinets, salons, and even smoking rooms, or as they were called a hookah lounge [8].

Towards the end of the $19^{\text {th }}$ century, the Russian bourgeoisie increasingly began to act as a customer along with representatives of noble dynasties. Next to the customer's enterprise, a two-story mansion of the owner of the iron foundry and mechanical plant F. K. San Galli (Ligovsky Prospect, 62; 18691872) was designed by architect Carl Rachau in the spirit of the Florentine palazzo. The mansion remains among the most famous examples of the eclectic decoration of the interior of the second half of the $19^{\text {th }}$ century. Rachau applied the practical experience of studying the Alhambra when creating a study in the Neo-Moorish style for the owner of the plant. In the design of this interior, the architect used the generally accepted Moorish architectural and decorative elements to decorate the walls and the ceiling. To the left of the entrance to the office, there was a white marble fireplace by sculptor I. Bott in the form of a dome of a mosque [7, p. 114]. An eight-beam gilded chandelier, draperies, furniture, carpets, paintings supported the overall style of the cabinet on the oriental theme. The interior deco- 


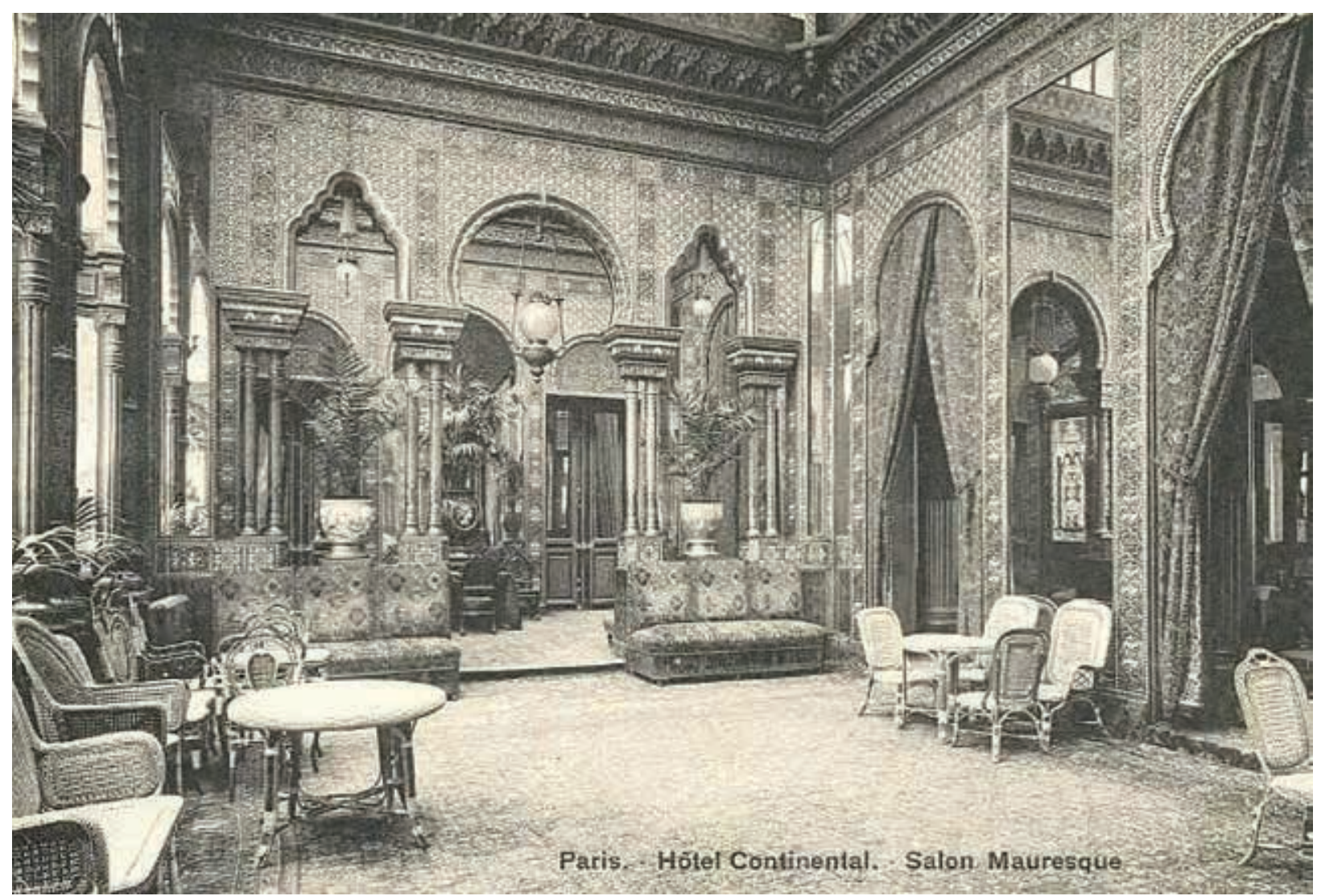

Ill. 4. Henri Blondel, Moorish Salon. Hotel Continental. Paris. 1878. Postcard

ration of each room was designed to the smallest detail. Furniture, chandeliers, forged parts, frames of paintings and mirrors, and fireplaces were made according to the architects' sketches. As evidenced by a photograph from the Architect journal for 1877, decorative fabrics and carpets were in the interior composition of the cabinet. The entire architectural and artistic interior decoration of the San Galli mansion was made in St. Petersburg according to Rachau's sketches. Only zinc dragons for drainpipes, made according to the drawing, were ordered from abroad - from Berlin and painted glass in the dining room, the work of the artist V. Sverchkov (18211888), were ordered from Munich [5, 74].

A magnificent example of the Moorish living room has been preserved in the mansion of baron and businessman S. P. von Derviz (1863-1918). In 1880, he commissioned academician of architecture P. Schreiber (1814-1903) to rebuild his house (Galernaya St., 33-35). Having reconstructed the facade of the mansion in the style of a Florentine palazzo of the $15^{\text {th }}$ century, the architect designed the ceremonial halls with various historical borrowings, among the styles of which were the Empire style, Elizabethan Baroque, and Modern Classicism. Following the trend, he also created a Moorish living room in the mansion. For the design of this hall, Schreiber applied new technology, covering the walls with openwork metal plates in gold. Through the drawing on gold plates, imitating painting, three colors are revealed: red, blue, and golden, harmoniously resonating with other elements of decoration (ill. 6). Classical forms in black marble dominate in the fireplace, which distinguishes this living room from other Neo-Moorish living rooms in which architects and sculptors sought to design fireplaces in the forms of intricate oriental architecture, thereby enhancing the unity of style expression.

The Moorish living room in the Yusupov Palace in St. Petersburg (94 Moika Embankment) is a good example of the Neo-Moorish style. Due to the process of transformation of this interior by different architects in the period from 1860 to 1890, the evolution of Eastern stylization from mixed borrowings to the exact copy of the Moorish samples of the Alhambra can be noticed. In the 1890s, architect A. Stepanov redesigned the Eastern drawing-room of architect I. A. Monighetti (1818-1878) into the Moorish one. The old name "Oriental" indicated a collective approach to the design of the oriental interior, which is evident in the daguerreotypes and watercolors of A. Redkovsky (1831-1909), 
whereas the new name "Moorish" shows the architect's desire to accurately reproduce the original source of the Alhambra. At the same time, with the choice of the Mauresque style, which has nothing to do with Russia, architect A. Stepanov completely made the interior of the hall in accordance with pan-European historicism.

Tall lancet arches on thin columns divide the space of the Moorish living room. The architect identified several levels for decoration in the layout of the walls of the room. The lower part is covered with tiles, which frame all the bends of the walls. Over the tiles, the architect built niches in the form of miniature horseshoe-shaped arches with thin columns. The surface of the walls is decorated with the finest carvings of arabesques with Kufic inscriptions. A carved coffered ceiling and its cornice are some of the important design elements. Windows and doors are made in the form of double arches and are closed with gilded bars. In imitation of the Moorish halls of the Alhambra, the fountain is located in the center of the living room. However, while the fountains in Andalusia performed a practical function along with the decorative one, maintaining coolness in the sultry heat, the fountain in St. Petersburg performs a purely decorative function and looks somewhat artificial, being in the same interior with a fireplace, the necessity of which is caused by the northern climate.

The apartment building of Prince A.D. Muruzi (1874-1876) is a rare example of the use of the NeoMoorish style (Liteiny Prospect, 24). The architect A. Serebryakov, with the participation of P. Shestov and N. Sultanov, designed not only a part of the interiors but also the exterior decoration of the facade in the Neo-Moorish style. Serebryakov proved to his contemporaries that, along with other historical styles, the Neo-Moorish design was applicable even to apartment buildings [11, p. 117-119].

The facade stood out among other apartment buildings on Liteiny Prospekt with horseshoe-shaped arches, stylized Arabic script, casings in the form of stalactites, cast grates with oriental ornaments, and terracotta columns. For his family, the Prince commissioned the design of apartments in the mezzanine consisting of 26 rooms. Prince Muruzi's apartments provided examples of the best borrowings from Rococo, Gothic; however, a great emphasis was placed on luxurious Moorish architecture [13].

In the $19^{\text {th }}$ century, the first most striking manifestations of the oriental theme were found in lit- erature and painting. The mysterious world of the East became a rich source for European artists and writers. Parallel to literature and painting, the oriental theme was developing in architecture and interior design. Publications, references to samples of oriental styles became more reliable and detailed with the increase of practical and restoration trips of architects and scientists. Gradually, historical monuments of oriental culture were selected, the architecture and decor of which would become models for European architects to which they would refer designing oriental decorations.

In the second half of the $19^{\text {th }}$ century, the NeoMoorish style became the most popular oriental borrowing, the most striking examples of which are presented in North Africa and Andalusia. The entry of Tunisia and Algeria into the sphere of colonial interests of France, as well as the geographical proximity of the historical monuments of the Alhambra in Andalusia, contributed to their study by European scientists and architects. Russian architects such as Notbek with his models and casts of the interiors of the Alhambra and Rachau and Colman, who developed the project for the restoration of the Infant tower, also distinguished themselves in the study of the Alhambra. Recognized both in Russia and in Europe, the results of their work allowed St. Petersburg architects to have accurate models of Moorish architecture, to develop this style and to modify it in many St. Petersburg interiors with a high degree of craftsmanship during the peak of historicism development.

By the middle of the $19^{\text {th }}$ century, the historical direction of Orientalism tended to move away from the illusory imaginary East in favor of a more scientific and detailed approach to creating oriental interiors. Thus, in the middle of the $19^{\text {th }}$ century, architects recreated the Moorish style of the Alhambra using their own experience or albums with detailed descriptions and sketches of geometric ornaments, Kufic inscriptions, and architectural forms already issued by that time. According to European understanding, at its initial stage of development, the Neo-Moorish style acted as a collective synonym for Muslim architecture. Gradually, this style received a more accurate definition based on the study of historical monuments. Owing to the rich historical component, the Moorish borrowings of the Alhambra harmoniously fitted into the interiors of eclecticism along with other retrospective styles.

In the second half of the $19^{\text {th }}$ century, the Moorish style spread throughout Europe and became an 


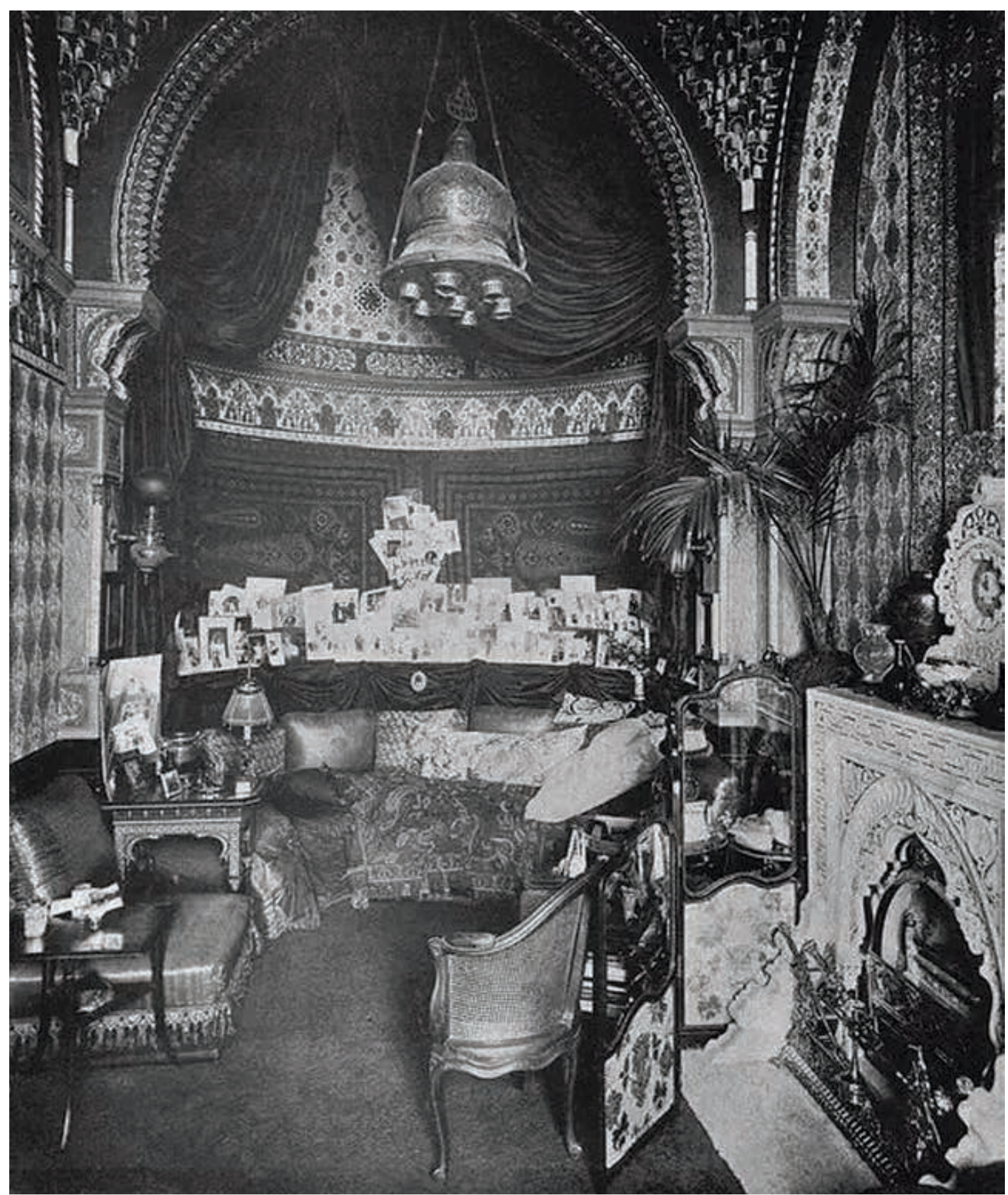

IIl. 5. A. I. Rezanov, Moorish boudoir. Vladimir Palace. Saint Petersburg. Photo by G. V. Baranovsky. The Architectural Encyclopedia of the Second Half of the $19^{\text {th }}$ Century in 7 Volumes. V. 4. Housing and Services. 1904

international historical oriental style. In each country, borrowings show their own characteristics and developmental features due to cultural, political, and geographical influence. France, working closely with the Maghreb countries and neighboring Spain, borrowed different variations of the Moorish style, from mixed stylistic examples to the Moorish-Tunisian borrowings and the (Spanish-Moorish) style of the Alham- bra. In France, the Moorish style is actively borrowed not only for interior decoration but also in the construction of public and commercial buildings such as casinos, cafes, thermal stations, exhibition halls.

Neo-Moorish interiors became an integral part in the design of mansions in Russia in the second half of the $19^{\text {th }}$ century. This is due to the pan-European tendency in the development of historicism and 


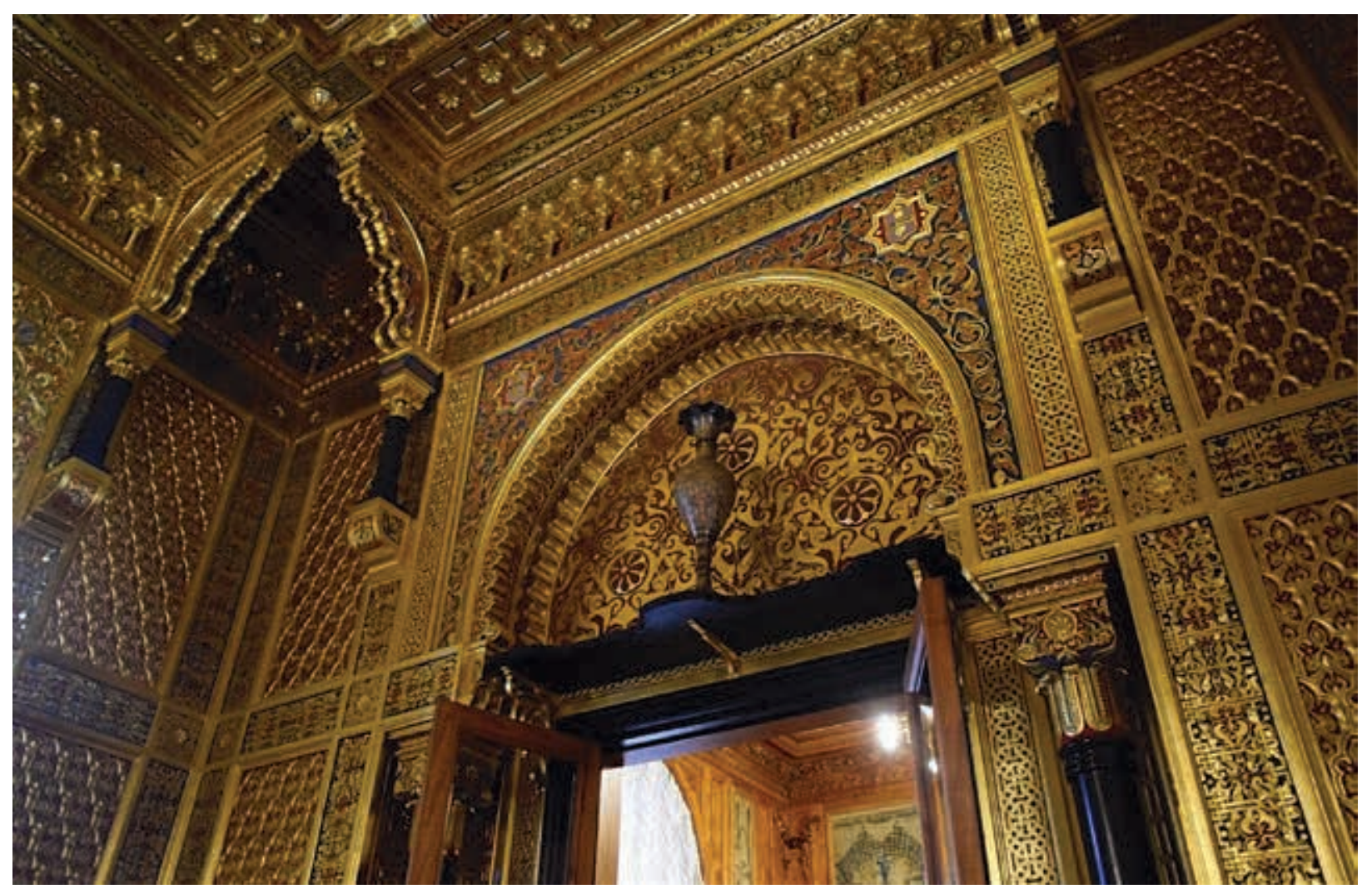

IIl. 6. P.P. Schreiber. Detail of the design of the Moorish living room in S. P. von Derviz's mansion. Photo by the author. 2018

Orientalism in architecture. However, the use of this historical style in Russia has a number of its own characteristics. Firstly, preference is given to the chamber decoration in the Moorish style against the background of a variety of other historical borrowings. Secondly, in comparison with France, there were practically no Moorish-style public buildings in Russia, with rare exceptions. Thirdly, in France, the neo-Moorish style took on various forms and sources, whereas in Russia, it refers mainly to the historical examples of the Alhambra.

Thus, France and Russia participated in the panEuropean trend for the Neo-Moorish style; however, each country has developed its own variation of this oriental style due to historical influences and a geographical location.

\section{REFERENCES}

1. Bashutsky, A. P. 1839. Vozobnovleniye Zimnego dvortsa $\checkmark$ Sankt-Peterburge [The Renewal of the Winter Palace in St. Petersburg], St. Petersburg, Guttenberg Printing House, p.136. (in Russian)

2. Biograficheskiye svedeniya o chlenakh Akademii i voobshche khudozhnikakh, umershikh v 1875-1878 gg. [Biographical Information on the Members of the Academy and the Artists in General Who Died in 1875-1878]. St. Petersburg, Printing House of the Imperial Academy of Sciences, 1879. p.51. (in Russian)

3. Botkin, V. P. 1857. Pis'ma ob Ispanii Botkin's [Letters on Spain]. St. Petersburg, p.448. (in Russian)

4. "Dom Ye. I. V. Velikogo knyazya Vladimira Aleksandrovicha" ["The House of His Royal Highness Grand Duke Vladimir Alexandrovich"], Zodchiy [Architect]. 1875. no. 7-8. pp. 89-90. (in Russian)
5. ["Dom-osobnyak g. San-Galli v Sankt-Peterburge"] "San Galli's Mansion in St. Petersburg", Zodchiy [Architect], 1877. no. 8, pp.74-75. (in Russian)

6. ["K. K. Rakhau. Biograficheskiy ocherk"] "C. Rachau. Biographical Sketch", Zodchiy [Architect], 1882. no. 1, pp.12-13. (in Russian)

7. "Kamin v dome g. F. San-Galli v SPb" ["The Fireplace in San Galli's House in St. Petersburg"], Zodchiy [Architect], 1877. no. 11-12, p. 114. F. 57. (in Russian)

8. Korobova, T. S. 2009. "Mavritanskiy stil'" v inter'yerakh dvortsov i osobnyakov vtoroy poloviny XIX - nachala XX veka na primere Peterburga i Moskvy ["The Moorish Style in the Interiors of Palaces and Mansions of the Second Half of the $19^{\text {th }}$ and Early $20^{\text {th }}$ Centuries on the Example of St. Petersburg and Moscow"], Sbornik materialov XV Tsarskosel'skoy nauchnoy konferentsii, Tsarskoye Selo, 30 noyabrya - 2 dekabrya 2009 goda. Ros- 
siya - Vostok: kontakt i konflikt mirovozzreniy. $v$ dvykh chastiakh [Proceedings of the XV Tsarskoye Selo Scientific Conference, Tsarskoye Selo, November 30 -December 2, 2009. Contact Between Russia and the East. The Conflict of Worldviews. In 2 parts], Part 1, St. Petersburg, State Hermitage Museum, pp. 245-257. (in Russian)

9. Muzey Akademii khudozhestv. Stranitsy istorii 17581990 [The Museum of the Academy of Arts. Pages of History. 1758-1990s]. St. Petersburg, 2009. p. 272. (in Russian)

10. Pushkin, A. S. 1986. Works in 3 volumes. V. 3. Prose. Moscow, p. 527. (in Russian)

11. "Khronika" ["Chronicle"], Zodchiy [Architect], 1875. no. 10, pp.117-119. (in Russian)

12. Choisy, O. 2009. Istoriya arkhitektury [History of Architecture], vol.2, Moscow, V. Shevchuk. p.462. (in Russian)

13. Yukhneva, Y., 2019. Peterburgskiye dokhodnyye doma. Ocherki iz istorii byta. [Apartment Buildings of Petersburg. Essays from the History of Life] (in Russian)

14. Beaucorps Gustave de (1825-1906), Bibliothèque nationale de France. Available at: https://data.bnf.fr/ fr/14977914/gustave_de_beaucorps/ (accessed on 08.06. 2020). (in French)

15. Decléty, L. Pratique et connaissance: les chemins divergents de l'orientalisme scientifique et de l'orientalisme artistique en France et en Allemagne, Institut national d'histoire de l'art. Available at: https://journals. openedition.org/inha/4920 (accessed on 08.06. 2020). (in French)

16. Dumas, A. Impression de voyage de Paris à Cadix, vol. 1,. Paris Michel Lévy Frères, libraires-éditeurs, rue Vivienne, 2 bis, 1861. p.306. (in French)

17. Elke Pflugradt-Abdel Aziz La proposition de l'architecte Carl von Diebitsch (1819-1869): I'architecture mudé- jare pour une civilisation globalisée, Institut national d'histoire de l'art. Available at: https://journals. openedition.org/inha/4919 (accessed on 08.06. 2020). (in French)

18. Explication des ouvrages de peinture, sculpture, gravure, lithographie et architecture des artistes vivants exposés au palais des Champs-Elysées le 1 mai 1863. Paris. Charles de Mourgues Frères, successeurs de Vanchon, imprimeurs des musées impériaux. Paris, 1863. (in French)

19. Gaillard, E. 2010. Walter M. Un certain gout pour l'Orient XVIII et XIX siècles. Editions Citadelle\&Mazenod. Paris. p.240. (in French)

20. Giraut de Prangey J-Philibert. Monuments arabes et moresques de Cordoue, Séville et Grenade, dessinés et mesurés en 1832 et 1833, 1836-1839. Edition Veith et Hauser. Paris, 1836. (in French)

21. Giese, F., Braga, A. V. 2019. "The Protagonists of the Moorish Revival: Translating Ibero-Islamic Heritage in Eighteenth- and Nineteenth-Century Europe", Art in Translation, vol.11, no.2, pp.119-123 DOI: 10.1080/17561310.2019.1703333 (in English)

22. Goblet, L. 1863. "Salon de 1863", Les Beaux-Arts. Revue de l'art ancien et moderne. Paris. vol. 7, p. 24. (in French)

23. Hugo, V. 1882. Les orientales. Edition George Chamerot. Paris. p.347. (in French)

24. Kaufmann, K. The "Splendor of the Caliph's Dwellings" in Saint Petersburg. Aleksandr Briullov as a Pioneer of Neo-Moorish Style in Russia, Art in Translation , vol.11, no.2, pp.181-199 DOI: 10.1080/17561310.2019.1658992 (in English)

25. Toulier, B. 2006. Un parfum d'Orient au cœur des villes d'eaux, Revue des patrimoines, no.7 (in French)

\section{UNPUBLISHED SOURCES}

1. RGIA F. 789 Op. 14. Litera N. Storage Unit 33 F. 20-21. Academy of Arts of the Ministry of the Imperial Court. Personal things. Notbek Pavel Karlovich. 20-21. 
Оксана Евгеньевна Мишуровская-Тертри

Санкт-Петербургский государственный академический институт живописи, скульптуры и архитектуры имени И.Е. Репина, факультет теории и истории искусств, e-mail: oksana.mt@mail.ru

Санкт-Петербург, Россия

ORCID 0000-0002-2528-1633

DOI: 10.36340/2071-6818-2020-16-2-70-90

\section{ОСОБЕННОСТИ РАЗВИТИЯ НЕОМАВРИТАНСКОГО СТИЛЯ НА ПРИМЕРЕ РОССИИ И ФРАНЦИИ}

Аннотация: В статье предлагается сравнительный анализ становления и развития неомавританского стиля в архитектуре и интерьерах Франции и России в XIX веке. Как формировался в этих странах интерес к изучению зодчества средневековых мавров? Какие главные отличия и сходства в развитии неомавританского стиля прослеживаются в России и Франции?

Первые проявления восточной темы в XIX веке появляются в значительной степени благодаря творчеству писателей и художников. Загадочный мир Востока становится богатым источником новых сюжетов, палитры, экзотичных нравов и архитектурных форм. Параллельно литературе и живописи, восточная тема развивается в архитектуре и оформлении интерьеров, которая достигнет наивысшего расцвета в копировании мавританского стиля. Среди памятников средневековых мавров архитектурным образцом для европейских зодчих становится дворец Альгамбры, построенный в Гранадском эмирате в период с XIII по XV век. Французские всемирные выставки, на которых выставлялись архитектурно-исторические павильоны, явились важным источником распространения неомавританского стиля в Европе. В изучение Альгамбры значимый вклад внесли также русские архитекторы, такие как П. К. Нотбек и К. К. Рахау. Результаты их работ, признанные как в России, так и в Европе, позволили петербургским архитекторам в период наивысшего развития историзма иметь подлинные образцы мавританского

Повышенный интерес к искусству Востока развивается в Европе на протяжении всего XVIII века. Первые проявления ориентализма в архитектуре обнаруживаются главным образом в европеизированном китайском стиле шинуазри как в одном из подстилей рококо. В начале XIX века под влиянием романтизма возрастает интерес к мусульманским культурам. А уже к середине XIX сто- зодчества и развивать этот стиль во многих интерьерах Санкт-Петербурга с высокой степенью мастерства в исполнении.

Во второй половине XIX века мавританский вкус распространяется по всей Европе и становится международным историческим ориентальным стилем. В каждой стране заимствования проявляют свои особенности и черты развития в силу культурно-политического и географического влияния. Мавританский вкус во Франции активно заимствуют не только для оформления интерьеров, но и при строительстве общественных и коммерческих сооружений, таких как казино, кафе, термальные станции. В России мавританский стиль нашёл применение в основном во дворцах и особняках высшей знати и буржуазии. Во Франции стиль мореск приобретает разнообразные формы и источники, в то время как в России он относится в основном к историческим образцам Альгамбры. Таким образом, Франция и Россия участвуют в общеевропейском течении моды на неомавританский стиль, но в каждой стране развивается своя собственная вариация этого ориентального стиля периода историзма.

Ключевые слова: неомавританский стиль, восточное направление, оформление интерьеров, восточные стилевые исторические заимствования, ориентализм, Альгамбра, историзм, сравнительная история искусств Франции и России.

летия неомавританский стиль становится наиболее востребованным историческим восточным заимствованием в архитектуре и художественном оформлении интерьеров Франции и России. Во Франции заимствование мавританского вкуса развивалось не только в результате общеевропейского течения историзма, но и в силу колонизации Северной Африки, территория которой, 
наряду с Андалузией, считается историческим регионом распространения этого направления. Русский ориентализм имел два источника: в связи с экспансией Российской империи на Восток (Кавказ и Средняя Азия) и одновременно - под влиянием западного ориентализма, что объясняет популярность неомавританского стиля среди русской знати.

Как во Франции, так и в России первые представления о Востоке развиваются благодаря живописи и литературе. В 1829 году французский писатель Виктор Гюго (1802-1885) в предисловии к своему сборнику «Восточные мотивы» отметит: «Сегодня у нас больше, чем когда-либо, занимаются Востоком. ...В век Людовика XIV мы были эллинистами, теперь мы ориенталисты» [23, р. 6]. Параллельно существующим восточным культурам, с которыми знакомились художники и писатели в ходе научных экспедиций и колониальной экспансии, развивается интерес к восточным культурам прошлого, которые оставили после себя богатое архитектурное и декоративное наследие. К таким памятникам прошлого романтики XIX века относили средневековое наследие восточных мавров. Мавританское искусство охватывает художественную культуру Северной Африки и Южной Испании времён арабского владычества. Главным архитектурным образцом этого стиля считается дворец Альгамбра, построенный в Гранадском эмирате с XIII по XV век.

В 1846 году Александр Дюма (Alexandre Dumas, 1802-1870), путешествуя по Испании вместе с художниками Луи Буланже (Louis Boulanger, 1806-1867) и Эженом Жиро (P.-F. Eugène Giraud, 1806-1881), проведёт несколько дней в Гранаде, которые он опишет в книге «Путевые заметки. Из Парижа в Кадис» (1847-1848). Дюма, как и многие другие писатели, передал своё восхищение архитектурой, орнаментом залов и двориков Альгамбры: «Когда вы оказываетесь в большом дворе, который носит три разных названия - «Миртовый дворик», «Двор с каналом» или «Двор с бассейном», (...) - вы помолодеете на пять веков, и вы определённо предпочтёте Восток Западу» [16, р. 281]. Впоследствии восточная тема развивается в литературных произведениях Дюма (в частности, в романе «Граф Монте Кристо»), тем самым участвуя в увлечённости многих французских писателей-романтиков ориентализмом. Путевые рисунки и картины художника Адриана Доза (A. Dauzats, 1804-1868) являются ещё одним интересным свидетельством, в котором он отразил участие в экспедиции на Ближний Восток и изучение мавританского наследия в Гранаде, Севилье, Кордове в 1836 году (ил. 1).

Благодаря культуре Востока художники открывают для зрителей новые живописные виды исламской архитектуры, яркую цветовую палитру, сюжетные композиции восточного быта и истории. Восточный жанр во Франции представляли Э. Делакруа (1798-1863) (Алжирские женщины в гареме» (1849)), Т. Шассерио (1819-1856) («Мавританский танец с платками» (1849)), Э. М.Ф. де Буалеконт (1849-1923) («Дворец наказаний в Альгамбре в Гранаде» (1878)) и многие другие.

Для русских писателей и художников XIX века источником вдохновения ориентальной темы первоначально становятся Крым и Кавказ после их вхождения в состав Российской империи за счёт Турции и Персии. Например, А. С. Пушкин (17991837) под влиянием романтизма и собственных наблюдений развивает восточную тему в ряде произведений («Бахчисарайский фонтан») и записках «Путешествие в Арзрум», в которых он описывает «роскошные» тифлисские бани и рассказывает о посещении действующего турецкого гарема, заключая: «таким образом, видел я харем: это удалось редкому европейцу. Вот вам основание для восточного романа» [10, с. 408]. В дальнейшем ориентализм расширяет свои границы, следуя общеевропейской моде, и некоторые художники и писатели обращаются напрямую к мавританской теме. Например, В.П. Боткин (1811-1869), в 1845 году путешествуя по Пиренейскому полуострову, в «Письмах об Испании» (1857) опишет экзотичность этой страны в силу культурного влияния и исключительного архитектурного наследия арабских мавров, сохранившегося отчасти в Севилье, Кордове и Альгамбре. В.П. Боткин пишет: «Мавританский элемент не только оставил глубокие следы в Андалусии: он сросся здесь со всем, его чувствуешь и в народных напевах фанданго, и в языке, и в обычаях, и в привычках» [3, с. 75]. Автор отмечает, что для жителей Европы XIX века характер и нравы Востока остаются загадочными и чуждыми европейской культуре.

В начале XIX века, следуя примеру художников и писателей, европейские архитекторы открывают для себя красоту и богатство мавританского зодчества. Многие посещают испанскую Андалузию не только для ознакомления с её архитектурой, но и для детального изучения, проведения 
обмеров, воспроизведения моделей и слепков. Изученный материал публикуется отдельными увражами, учебными пособиями, разрабатываются курсы лекций по мавританскому декору.

В 1836 году французский художник и фотограф, специализирующийся в архитектуре, Ж.-Ф. Жиро де Пранже (J.-P. Girault de Prangey, 1802-1892), публикует сравнительный анализ андалузских, арабских и египетских архитектурных памятников в книге ${ }^{1}$ «Арабские и мавританские сооружения в Кордове, Севилье и Гранаде, с зарисовками и обмерами в 1832 и 1833, 1836-1839» [20]. В этой публикации автор рассматривает Альгамбру как наиболее совершенный образец мавританского зодчества для подражания. В своей поездке по Востоку Ж.-Ф. Жиро де Пранже одним из первых использует возможности дагерротипов, благодаря которым до наших дней сохранились уникальные изображения памятников восточной архитектуры и их орнаментов. С развитием калотипии ${ }^{2}$ во Франции появляются в конце 1850-х годов первые фотографии залов Альгамбры, сделанные Жаном Лораном (Jean Laurent, 1816-1886) и Гюставом де Бокором (Gustave de Beaucorps,1825-1906) [14] (ил. 2).

В России к середине XIX века ученики Императорской академии художеств начинают интересоваться «российским востоком», посещая Среднюю Азию и Закавказье [9, с. 217]. К маршрутам пенсионеров Академии по Европе кроме изучения классических памятников добавились памятники мавританского зодчества Андалузии. Среди пенсионерских работ появляются труды, посвящённые мавританской архитектуре Альгамбры, по мастерству признанные и отмеченные наградами не только в России, но и за рубежом.

Особый интерес представляет деятельность П. К. Нотбека (1824-1877), который на протяжении десяти лет работал в Альгамбре над зарисовками мавританского зодчества, созданием моделей отдельных залов и слепков орнаментов. Благодаря доставленным в Россию работам П.К. Нотбека в музее Императорской академии художеств откроют отдел, посвящённый мавританской архитектуре и декору. Экспозиция состояла из 284 наименований, в состав которой входили

1. Один из оригинальных экземпляров на французском языке хранится в Российской национальной библиотеке СПб.

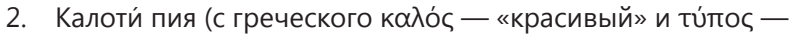
«отпечаток») - ранний фотографический процесс, основанный на использовании бумаги, пропитанной йодистым серебром.
«Зал двух сестёр» в размере $1 / 4$ настоящей величины, «Залы Абенсерахов» в $1 / 12$ величины, модели одной стены из «Зала посланников» в $1 / 8$ величины, одной половины «Львиного двора» в $1 / 12$ величины и другие [2, с. 40-42]. В составе прибывшей коллекции находились также подлинные мавританские капители, которые П.К. Нотбек смог приобрести. В настоящее время часть сохранившейся коллекции моделей и слепков Альгамбры П. К. Нотбека находится в Научноисследовательском музее Российской академии художеств в Санкт-Петербурге.

За создание мавританских моделей и слепков П.К. Нотбека производят в почётные вольные общники Императорской академии художеств и награждают орденом Св. Анны 3-й степени [26, л. 21].

Работу П.К. Нотбека в Альгамбре продолжили другие стипендиаты Императорской академии художеств, среди которых отличились К. К Рахау (1830-1880) и К.К. Кольман (1835-1889). Одним из результатов их совместной работы во время пребывания в Андалузии стал проект реставрации башни Инфант во дворце Альгамбры в Гранаде, который отметили высокой оценкой во Франции. Об этом событии в журнале «Зодчий» даются следующие сведения: «Известно, однако, что прекрасный труд его, исполненный въ сотрудничестве съ товарищемъ по пенсіонерству К.К. Кольманомъ, проектъ рөставраціи дворца Альгамбры въ Гренаде, еще до прибытія въ С.-Петербургъ, вызвалъ удивленіе и одобреніе въ Европе: на Парижской выставке 1862 года ему присуждена была золотая медаль, а въ Мюнхене выданъ одобрительный почетный дипломъ. Возвратясь въ 1864 году, въ С.- Петербургъ К. К. Рахау былъ возведенъ въ званіе академика» [6, с. 12-13] ${ }^{3}$. Согласно французским источникам, русские архитекторы представили проект реставрации в 1863 году [22] на ежегодном парижском салоне, организованном французским Министерством императорского дома и изящных искусств [18, р. 387].

Подробное изучение средневековых мавританских памятников Испании, в особенности Альгамбры, способствовало быстрому развитию заимствования неомавританского стиля в архитектуре и оформлении интерьеров. Этот восточный стиль становится частью историзма, который приходит на смену классическому стилю. Во второй половине XIX века, в отсутствие собственного

3. В тексте сохранены особенности орфографии и пунктуации оригинального источника журнала «Зодчий». 
для этого периода «большого стиля», равнозначными признаются все направления. Такой подход назовут эклектикой, что означает по-гречески «разумный выбор». Оформление интерьеров в подражательных стилях воспроизводят в штукатурной отделке, разрабатываются новые недорогие методы изготовления декоративных форм. В одном архитектурном пространстве соединяют разные стилистические заимствования, среди которых особой популярностью начинают пользоваться рококо, готика, французская классика и т.д. Мавританский интерьер, как один из художественных стилей прошлого, становится также частью «умного выбора» архитекторов.

Воссоздавая исторический стиль мавританского зодчества, архитекторы заимствуют наиболее характерные его элементы: тонкие колонки, арки (стрельчатые, подковообразные, трёхлопастные), сталактиты в сводах и нишах. Существенным элементом декора выступают окна и двери, закрываемые резными позолоченными решётками из тонкого алебастра, дерева или кованого металла. Арабеска выступает основным орнаментом, который распространяется практически по всей поверхности стен. Декоративную отделку дополняют куфические надписи [12, с. 103]. Полихромия и фактура интерьера отличаются большим разнообразием.

Восточные интерьеры архитекторы проектировали не только под влиянием развития историзма, но и по желанию самих заказчиков, посетивших восточные страны, среди которых были писатели, путешественники и представители буржуазии. Одним из ярких примеров до настоящего времени остаётся мавританский салон французского писателя Александра Дюма (1802-1870). По его заказу в построенном под Парижем дворце «МонтеКристо» в стиле неоренессанс (1847), тунисские мастера оформили «мавританский салон» (фр. «salon mauresque») наподобие тех образцов, которые писатель видел в Испании и Северной Африке. Стены и потолок салона покрывают резным стюковым орнаментом. Причудливая резьба по штукатурке чередуется с лепными барельефными сталактитами на стенах. Три массивные подковообразные арки делят пространство салона на две части. Интерьер дополняли светильники с разноцветными стёклами, восточная мебель, курильницы, резные столики. Разноцветные витражи на окнах акцентируют внимание на эклектическом характере интерьера середины XIX века (ил. 3).
Во Франции в мавританском стиле оформляют не только интерьеры во дворцах и частных особняках, как в России. Эта мода ярко проявила себя при строительстве общественных зданий. В немалой степени этому способствовали стремительное развитие экономики и расширение типов сооружений по функциональному назначению: проектируются новые гостиницы, банки, доходные дома, крытые рынки, вокзалы, зоны отдыха.

Экзотика Востока привлекает французскую буржуазию для смены обстановки и приятного времяпрепровождения. В курортном городе Виши по проекту французского архитектора Антуана Персильи (Antoine Percilly, 1858-1928) в 1898 году строят кафе в стиле мореск (с фр.- «мавританский»). В 1860 году компания «Южные железные дороги», возглавляемая братьями Перейр (Pereire), возводит в городе Аркашон (Arcachon) люксовый ансамбль зимних вилл, среди которых отдельные стилизованы в мавританском вкусе [19, р. 202]. Через три года для состоятельных клиентов Аркашона по проекту инженера Поля Реньо (Paul Régnauld, 1827-1879) строят казино. Здание выполнено в испано-мавританском стиле, для которого заимствовались конструктивные и декоративные элементы дворца Альгамбры в Гранаде и мечети в Кордове [25].

Во Франции строительство целых ансамблей в неомавританском стиле можно объяснить влиянием общеевропейской моды, а также французской колониальной политикой в Северной Африке. Примечательно, что французские архитекторы проектируют сооружения в стиле мореск не только в самой Франции, но и в её мусульманских колониях (Алжир, Тунис). В своих работах зодчие активно заимствуют местные образцы и вариации мавританского стиля, часто дополняя их отдельными элементами европейской архитектуры.

Всемирные выставки в европейских столицах явились ещё одним из источников распространения моды на восточную архитектуру и декоративно-прикладное искусство. Наиболее понравившиеся модели приобретали у создателей или заказывали их копии. В Париже, на выставке 1867 года, в прусском отделе архитектор Карл фон Дибич (Carle von Diebitsch, 1819-1869) представил «мавританский павильон». Внутреннюю отделку павильона полностью выполнили по испано-мавританским образцам, включая мебель и ткани. Центром композиции павильона стала большая люстра в мавританском стиле 
с разноцветным стеклом, под которой располагался фонтан - неотъемлемая часть мавританского оформления [17].

По случаю Всемирной выставки 1878 года в Париже строят дворец Трокадеро по проекту архитекторов периода Наполеона III Габриеля Давиу (Gabriel Davioud, 1824-1881) и Жуля Бурде (Jules Bourdais, 1835-1915). Здание проектируют, заимствуя одновременно элементы мавританского и византийского зодчества. Прототипом для форм мавританского заимствования стала мавританская башня Хиральды в Севилье [25].

Одновременно к этой выставке в гостинице «Континенталь» - одном из символов парижского люкса - оформляют зал в стиле Альгамбры по проекту французского архитектора Анри Блонделя (Henri Blondel, 1821-1897) [15]. Мавританский зал в гостинице «Континенталь» отличался богатой отделкой стен стилизованным растительным и геометрическим орнаментом. Из архитектурных элементов, украшавших зал, заимствовали ажурные подковообразные и многолопастные арки, поддерживаемые тонкими сдвоенными колонками с узорными капителями. Богато орнаментированный карниз дополнял художественное оформление. Большие арочные окна позволяли хорошо освещать салон дневным светом. Художественное оформление интерьера дополнили стилизованными светильниками, узорчатыми драпировочными тканями, приземистыми диванами и обилием цветов (ил. 4).

Неомавританские мотивы находят применение не только в архитектурных формах и оформлении интерьеров, но и в декоративно-прикладном искусстве. Например, во Франции орнамент андалузского декора воспроизводится на обоях производителей Дефоссе и Карт (Desfossé et Karth) с 1857 года [19, р. 188].

В России в первой половине XIX века ведущим восточным заимствованием являлся турецкий стиль - в силу культурного взаимодействия с Оттоманской империей, за счёт которой Россия расширяла свои границы с конца XIX века. В интерьерах русской знати появляются предметы турецкого быта, коллекции оружия, приходит мода на восточную одежду, ткани, головные уборы. Для хранения подобных коллекций в великокняжеских дворцах и особняках проектируются восточные кабинеты и нередко - павильоны в прилегающих садах.

Под влиянием Западной Европы к турецкому заимствованию постепенно добавляется мода на неомавританский стиль, который получил в России довольно широкое применение. Современные западноевропейские исследователи отмечают значимость Санкт-Петербурга в сравнительном изучении развития этого стиля: «Санкт-Петербург - город, в котором широко представлены интерьеры в неомавританском стиле и где многие из них сохранились до наших дней, в отличие от Западной Европы» [21].

В 1839-1840 годы А. П. Брюллов (1798-1877) оформляет для Императрицы в Зимнем дворце Мавританскую ванную, которая стала первым примером неомавританского заимствования, перенесённого на русскую почву [24]. В книге «Возобновление Зимнего дворца в Санкт-Петербурге» русский писатель А.П. Башуцкий (1803-1876) оставил описание первого интерьера в мавританском вкусе, которое подтверждает восторженное восприятие современников этого исторического заимствования: «Вся роскошь гренадских Мавров; дивный характер волшебных вымыслов своенравного искусства востока отпечатан здесь на всём с полнейшей верностью. (...). Да, художник похитил всё это из Альямбры (орфография автора), и верно никто не поставит ему в вину этого похищения. Рельефные разных цветов и золотые украшения и арабески прилегли к стенам и своду, устлав комнату сверху до низа фантастическими узорами; местами высятся чудного стиля колонны; (...) мраморная углублённая ванна, под самим зеркалом, из которого по произволу бьёт хрустальным ключом горячая или холодная вода, сперва в огромную раковину, а из неё каскадами в ванну» [1, с. 117]. Судя по описанию Башуцкого, архитектор А.П. Брюллов уже в конце 1830-х годов закладывает основы развития неомавританского стиля в России.

Во Владимирском дворце (Дворцовая наб. д. 26) князя Владимира Александровича, перестроенном в 1867-1872 годах архитектором А.И. Резановым (1817-1887), в апартаментах княгини оформили небольшой будуар в неомавританском стиле.

Убранство будуара, описанное в журнале «Зодчий» от 1875 года [4, с. 89-90], хорошо сохранилось до наших дней. В плане это небольшое по размерам камерное помещение, единственное окно которого выходит на Неву и Петропавловскую крепость. Контраст отделочных материалов подчёркивает трёхчастное деление стен. Нижний пояс окрашен под имитацию изразцовой плит- 
ки залов Альгамбры, а средний покрыт лепным гипсовым орнаментом. Основное богатство орнаментики архитектор выносит на потолок, его своды и архитектурные элементы (ил. 5).

Кроме будуаров и ванных комнат, мавританский стиль широко применялся для оформления кабинетов, салонов и даже курительных комнат, или, как ещё их называли, кальянных [8].

K концу XIX века российская буржуазия всё чаще начинает выступать в роли заказчика наравне с представителями дворянских династий. Двухэтажный особняк владельца чугунолитейного и механического завода Ф.К. Сан-Галли (Лиговский пр., д. 62; 1869-1872 годы) архитектор К. К. Рахау спроектировал в духе флорентийского палаццо рядом с предприятием заказчика. Особняк остаётся среди наиболее известных примеров эклектического оформления интерьера второй половины XIX столетия. Практический опыт изучения Альгамбры К. К. Рахау применил при создании рабочего кабинета в неомавританском стиле для владельца завода. В оформлении этого интерьера архитектор использовал общепринятые мавританские архитектурные и декоративные элементы для убранства стен и потолка. Слева от входа в кабинет расположили камин из белого мрамора работы скульптора И. К. Ботта в форме купола мечети [7, с. 114]. Восьмилучевая позолоченная люстра, драпировки, мебель, ковры, картины поддерживали общую стилистику кабинета на восточную тему. Внутренняя отделка каждого помещения прорабатывалась до мельчайших деталей. По составленным эскизам архитекторов выполнялись мебель, люстры, кованые детали, обрамления картин и зеркал, камины. Как свидетельствует фотография из журнала «Зодчий» за 1877 год, в интерьерную композицию кабинета вписывались декоративные ткани и ковры. Всю внутреннюю архитектурную и художественную отделку особняка Сан-Галли произвели в СанктПетербурге по эскизам К. К. Рахау. За границей заказали лишь драконов из цинка для водосточных труб, выполненных по рисунку в Берлине, и живопись на стекле в столовой - произведение художника В.Д. Сверчкова (1821-1888) в Мюнхене $[5,74]$.

Великолепный пример мавританской гостиной сохранился в особняке барона и предпринимателя С. П. фон Дервиза (1863-1918). В 1880 году по его заказу академик архитектуры П.П. Шрейбер (1814-1903) перестраивает его дом (Галерная ул, д. 33-35). Реконструировав фасад особняка в стиле флорентийского палаццо XV века, архитектор оформляет парадные залы в различных исторических заимствованиях, среди которых - ампир, елизаветинское барокко, классицизм, модерн. Следуя моде, в особняке он создаёт и мавританскую гостиную. Для оформления этого зала П.П. Шрейбер применил новую технологию, покрывая стены ажурными металлическими пластинами под золото. Через рисунок золотых пластин, имитирующих роспись, просвечиваются три цвета - красный, синий и золотистый, - которые гармонично перекликаются с другими элементами убранства (ил. 6). В оформлении камина преобладают классические формы в чёрном мраморе, что отличает эту гостиную от других неомавританских гостиных, в которых архитекторы и скульпторы стремились проектировать камины в формах замысловатой восточной архитектуры, тем самым усиливая единство стилевого выражения.

Показательным примером цитирования неомавританского стиля является мавританская гостиная в доме Юсуповых в Санкт-Петербурге (Набережная Мойки, д.94). В процессе преобразования этого интерьера разными архитекторами в период с 1860 по 1890 год можно проследить эволюцию восточной стилизации от смешанных заимствований до точного копирования мавританских образцов Альгамбры. В 1890-е годы архитектор А. А. Степанов переоформляет «Восточную гостиную» архитектора И.А. Монигетти (1818-1878) в «Мавританскую». Если старое название - «Восточная» - указывало на собирательный подход в оформлении ориентального интерьера, что очевидно в дагерротипах и акварелях А. А. Редковского (1831-1909), то новое - «Мавританская» - показывает стремление архитектора к точному воспроизведению первоисточника Альгамбры. В то же время с выбором стиля мореск, который не имеет никакого отношения к России, архитектор А. А. Степанов полностью вписывает интерьер зала в общеевропейское русло историзма.

Высокие стрельчатые арки на тонких колонках делят пространство мавританской гостиной. В разбивке стен помещения архитектор выделяет несколько уровней для декорирования. Нижняя часть облицована изразцовой плиткой, которая лентой обрамляет все изгибы стен. Над изразцовой плиткой архитектор встраивает ниши в форме миниатюрных подковообразных арок с тонкими 
колонками. Поверхность стен украшена тончайшей резьбой арабесок с куфическими надписями. Одним из важных элементов оформления выступают резной кессонированный потолок и его карниз. Окна и двери выполнены в форме сдвоенных арок и закрываются позолоченными решётками. В подражание мавританским залам Альгамбры, фонтан располагается в центре гостиной. Однако если в Андалузии фонтаны выполняли, наряду с декоративной, практическую функцию, поддерживая прохладу в знойную погоду, то в Санкт-Петербурге фонтан выполняет чисто декоративную функцию и выглядит несколько искусственно, находясь в одном интерьере с камином, необходимость которого обусловлена северным климатом.

Редким примером применения неомавританского стиля является доходный дом князя А. Д. Мурузи (1874-1876) (Литейный пр., д. 24). Архитектор А.К. Серебряков при участии П.И. Шестова и Н. В. Султанова проектирует в неомавританском стиле не только часть интерьеров, но и наружную отделку фасада. А. К. Серебряков доказывает своим современникам, что, наряду с другими историческими стилями, неомавританское оформление применимо даже для доходных домов [11, с. 117-119].

Фасад выделялся среди других доходных домов на Литейном проспекте подковообразными арками, стилизованной арабской вязью, наличниками в форме сталактитов, литыми решётками с восточным орнаментом, терракотовыми колоннами. Для своей семьи князь оформляет апартаменты в бельэтаже, состоящие из 26 комнат. Апартаменты князя Мурузи представляли примеры лучших заимствований рококо, готики, но самый большой акцент делался на цитирование роскошной мавританской архитектуры [13].

B XIX веке первые наиболее яркие проявления восточной темы обнаруживают себя в литературе и живописи. Загадочный мир Востока становится богатым источником для европейских художников и писателей. Параллельно литературе и живописи, восточная тема развивается в архитектуре и оформлении интерьера. С увеличением практических и реставрационных поездок архитекторов и учёных, публикаций ссылки на образцы восточных стилей становятся более достоверными и детальными. Постепенно отбираются исторические памятники ориентальной культуры, чьи архитектура и декор станут образ- цами-моделями для европейских архитекторов, на которые те будут ссылаться при оформлении восточных убранств.

Во второй половине XIX века самым популярным восточным заимствованием становится неомавританский стиль, наиболее яркие образцы которого представлены в Северной Африке и Андалузии. Вхождение Туниса и Алжира в сферу колониальных интересов Франции, а также географическая близость исторических памятников Альгамбры в Андалузии способствуют их изучению европейскими учёными и архитекторами. В изучении Альгамбры отличились также и русские архитекторы, такие как П.К. Нотбек с моделями и слепками интерьеров Альгамбры, а также K. К. Рахау и К. К. Кольман, разработавшие проект реставрации башни Инфант. Результаты их работ, которые получили признание как в России, так и в Европе, позволили петербургским архитекторам в период наивысшего развития историзма иметь точные модели мавританского зодчества, развивать этот стиль и варьировать во многих интерьерах Санкт-Петербурга с высокой степенью мастерства в исполнении.

Историческое направление ориентализма к середине XIX века стремится отойти от иллюзорно воображаемого Востока в пользу более научного и детального подхода при создании восточных интерьеров. Так, в середине XIX века архитекторы воссоздают мавританский стиль Альгамбры, пользуясь собственным опытом или уже вышедшими к этому времени увражами с подробным описанием и зарисовками геометрических орнаментов, куфических надписей и архитектурных форм. Неомавританский стиль на начальном этапе развития в европейском понимании выступал как собирательный синоним мусульманской архитектуры. Постепенно этот стиль получает более точную интерпретацию, основанную на изучении исторических памятников. Благодаря богатой исторической составляющей мавританские заимствования Альгамбры гармонично вписываются в интерьеры эклектики наряду с другими ретроспективными стилями.

Во второй половине XIX века мавританский вкус распространяется по всей Европе и становится международным историческим ориентальным стилем. В каждой стране заимствования проявляют свои особенности и черты развития в силу культурно-политического и географического влияния. Франция, тесно взаимодействуя 
со странами Магриба и соседствуя с Испанией, заимствует разные вариации мавританского стиля - от смешанных стилизаторских вариантов до мавритано-тунисских заимствований и (испаномавританского) стиля Альгамбры. Мавританский вкус во Франции активно заимствуют не только для оформления интерьеров, но и при строительстве общественных и коммерческих сооружений, таких как казино, кафе, термальные станции, выставочные павильоны.

Неомавританские интерьеры становятся неотъемлемой частью в оформлении особняков в России во второй половине XIX века. Это связано с общеевропейской тенденцией развития историзма и ориентализма в архитектуре. Однако применение этого исторического стиля в России имеет ряд своих особенностей. Во-первых, отдаётся предпочтение камерному оформлению в мавританском вкусе на фоне разнообразия других исторических заимствований. Во-вторых, по сравнению с Францией в России практически не было общественных сооружений в мавританском стиле, за редким исключением. В-третьих, если неомавританский стиль во Франции приобретает разнообразные формы и источники, то в России он относится в основном к историческим образцам Альгамбры.

Таким образом, Франция и Россия участвуют в общеевропейском течении моды на неомавританский стиль, но в каждой стране развивается своя собственная вариация этого восточного стиля в силу исторических влияний и географического положения.

\section{БИБЛИОГРАФИЯ}

1. Башуцкий А.П. Возобновление Зимнего дворца в Санкт-Петербурге. СПб.: Гуттенберг типография, 1839. 136 c.

2. Биографические сведения о членах Академии и вообще художниках, умерших в 1875-1878 гг. СПб.: типография Императорской академии наук, 1879. 51 с.

3. Боткин В.П. Письма об Испании В.П. Боткина. СПб.: типография Эдуарда Праца, 1857. 448 с.

4. Дом Е.И.В. Великого князя Владимира Александровича // Зодчий. 1875. № 7-8. С. 89-90.

5. Дом-особняк г. Сан-Галли в Санкт-Петербурге // Зодчий. 1877. № 8. С. 74-75.

6. К.К. Рахау. Биографический очерк // Зодчий. 1882. № 1. C. 12-13.

7. Камин в доме г. Ф. Сан-Галли в СПб // Зодчий. 1877. № 11-12. С. 114. Л. 57.

8. Коробова Т.С. «Мавританский стиль» в интерьерах дворцов и особняков второй половины XIX - начала XX века на примере Петербурга и Москвы // Сборник материалов XV Царскосельской научной конференции, Царское Село, 30 ноября - 2 декабря 2009 года. Россия - Восток: контакт и конфликт мировоззрений. В 2-х ч. Ч. 1. СПб.: Государственный Эрмитаж, 2009. С. 245-257.

9. Музей Академии художеств. Страницы истории. 1758-1990-е годы. СПб.: Лики России, 2009. 272 с.

10. Пушкин А. С. Сочинения в 3-х т. Т. 3. Проза. М.: Худ. литература, 1986. 527 с.

11. Хроника. // Зодчий. 1875. № 10. С. 117-119.

12. Шуази О. История архитектуры в 2-х т. Т. 2. / Пер. с фр. 5-е изд. М.: В. Шевчук, 2009. 426 с.

13. Юхнева Е. Петербургские доходные дома. Очерки из истории быта// История государства [Электронный ресурс]. [URL]: https://statehistory.ru/ books/YUkhnyeva-E-D-_Peterburgskie-dokhodnye- doma - Ocherki-iz-istorii-byta-/3 (дата обращения: 01.06.2019).

14. Beaucorps Gustave de (1825-1906) // Bibliothèque nationale de France [Электронный ресурс]. [URL]: https://data.bnf.fr/fr/14977914/gustave_de_beaucorps (дата обращения: 01.06.2019).

15. Decléty L. Pratique et connaissance: les chemins divergents de l'orientalisme scientifique et de l'orientalisme artistique en France et en Allemagne // Institut national d'histoire de l'art [Электронный pecypc]. [URL]: https://journals.openedition.org/ inha/4920 (дата обращения: 04.06.2019).

16. Dumas A. Impression de voyage de Paris à Cadix. Volume I. Paris: Michel Lévy Frères, libraires-éditeurs, rue Vivienne, 2 bis, 1861. 306 p.

17. Elke Pflugradt-Abdel Aziz La proposition de l'architecte Carl von Diebitsch (1819-1869): I'architecture mudéjare pour une civilisation globalisée // Institut national d'histoire de l'art [Электронный ресурс]. [URL]: https:// journals.openedition.org/inha/4919 (дата обращения: 03.06.2019).

18. Explication des ouvrages de peinture, sculpture, gravure, lithographie et architecture des artistes vivants exposés au palais des Champs-Elysées le 1 mai 1863 Paris. Charles de Mourgues Frères, successeurs de Vanchon, imprimeurs des musées impériaux. Paris, 1863.

19. Gaillard E., Walter M. Un certain gout pour l'Orient XVIII et XIX siècles. Editions Citadelle\&Mazenod. Paris, 2010. $240 \mathrm{p}$.

20. Giraut de Prangey J-Philibert. Monuments arabes et moresques de Cordoue, Séville et Grenade, dessinés et mesurés en 1832 et 1833, 1836-1839. Edition Veith et Hauser. Paris, 1836.

21. Giese F., Braga A.V. The Protagonists of the Moorish Revival: Translating Ibero-Islamic Heritage in 
Eighteenth- and Nineteenth-Century Europe // Art in Translation [Электронный ресурc]. [URL]: https://www. tandfonline.com/doi/full/10.1080/17561310.2019.170 3333 (дата обращения: 01.04.2020).

22. Goblet L. Salon de 1863 // Les Beaux-Arts. Revue de I'art ancien et moderne. Paris,. 1863. T. 7. P. 24.

23. Hugo V. Les orientales. Edition George Chamerot. Paris, 1882. 347 p.

24. Kaufmann K. The «Splendor of the Caliph's Dwellings» in Saint Petersburg. Aleksandr Briullov as a Pioneer of
Neo-Moorish Style in Russia // Art in Translation [Электронный ресурс]. [URL]: https://www.tandfonline.com/ doi/abs/10.1080/17561310.2019.1658992 (дата обращения: 01.04.2020).

25. Toulier B. Un parfum d'Orient au cœur des villes d'eaux // Revue des patrimoines [Электронный ресурс]. [URL]: https://journals.openedition.org/insitu/3069 (дата обращения: 01.06.2019).

\section{НЕОПУБЛИКОВАННЫЕ ИСТОЧНИКИ}

1. РГИА Ф. 789 Оп. 14. Литера Н. Ед. хр. 33. Л. 20-21. Академия художеств Министерства императорского двора. Личные дела. Нотбек Павел Карлович. 